\title{
PRESIDENTIAL APPOINTMENTS TO THE SUPREME COURT
}

\author{
William H. Rehnquist*
}

\begin{abstract}
Justice Rehnquist was a "Jurist in Residence" at the University of Minnesota Law School for several days in October 1984. He delivered the following address on October 19. The topic is as timely now as it was then. We are, therefore, most grateful for Justice Rehnquist's permission to publish the speech.
\end{abstract}

One of the proud and just boasts of the constitutional system of government that we have in the United States is that even the President is not above the law. The justness of the boast is illustrated by decisions such as the Steel Seizure Case, in which the Court rebuffed the claims of President Truman, and the Nixon Tapes Case, in which the Court rebuffed the claims of President Nixon. But though the President, the head of the executive branch, may be subject under our system to checks and balances administered by the judicial branch of government, the courts themselves are subject to a different form of check and balance administered by the President. Vacancies in the federal judiciary are filled by the President with the advice and consent of the United States Senate. Just as the courts may have their innings with the President, the President comes to have his innings with the courts. It seems fitting, particularly in the year of a presidential election, to inquire what history shows as to the propensity of Presidents to "pack" the Court, and the extent to which they have succeeded in any such effort.

I use the word "pack" as the best verb available, realizing full well that it has a highly pejorative connotation. But it ought not to have such a connotation when used in this context; the second edition of Webster's unabridged dictionary, which happens to be the one I have in my study, defines the verb "pack" as "to choose or arrange (a jury, committee, etc.) in such a way as to secure some advantage, or to favor some particular side or interest." Thus a President who sets out to "pack" the Court seeks to appoint people to the Court who are sympathetic to his political or philosophical principles.

- Associate Justice, United States Supreme Court. 
There is no reason in the world why a President should not do this. One of the many marks of genius which our Constitution bears is the fine balance struck in the establishment of the judicial branch, avoiding both subservience to the supposedly more vigorous legislative and executive branches, on the one hand, and total institutional isolation from public opinion on the other. The performance of the judicial branch of the United States government for a period of nearly two hundred years has shown it to be remarkably independent of the other coordinate branches of that government. Yet the institution has been constructed in such a way that the public will, in the person of the President of the United States-the one official who is elected by the entire nation-have something to say about the membership of the Court, and thereby indirectly about its decisions.

Surely we would not want it any other way. We want our federal courts, and particularly the Supreme Court of the United States, to be independent of popular opinion when deciding the particular cases or controversies that come before them. The provision for tenure during good behavior and the prohibition against diminution of compensation have proved more than adequate to secure that sort of independence. The result is that the Justices are responsible to no electorate or constituency. But the manifold provisions of the Constitution with which judges must deal are by no means crystal clear in their import, and reasonable minds may differ as to which interpretation is proper. When a vacancy occurs on the Court, it is entirely appropriate that that vacancy be filled by the President, responsible to a national constituency, as advised by the Senate, whose members are responsible to regional constituencies. Thus, public opinion has some say in who shall become Justices of the Supreme Court.

The answer to the first question I posed-have Presidents in the past attempted to "pack" the Court-is easy; the Presidents who have been sensible of the broad powers that they have possessed, and been willing to exercise those powers, have all but invariably tried to have some influence on the philosophy of the Court as a result of their appointments to that body. This should come as a surprise to no one.

The answer to the second question that I posed-how successful have Presidents been in their efforts to pack the Court-is more problematical. I think history teaches us that those who have tried have been at least partially successful, but that a number of factors militate against a President having anything more than partial suc- 
cess. What these factors are I will try to illustrate with examples from the history of the Court.

Very early in the history of the Court, Justice William Cushing, "a sturdy Federalist and follower of Marshall," died in September 1810. His death reduced the seven-member Court to six, evenly divided between Federalist appointees and Republican appointees. Shortly after Cushing's death, Thomas Jefferson, two years out of office as President, wrote to his former Secretary of the Treasury, Albert Gallatin, in these unseemingly gleeful words:

I observe old Cushing is dead. At length, then, we have a chance of getting a Republican majority in the Supreme judiciary. For ten years has that branch braved the spirit and will of the Nation . . . . The event is a fortunate one, and so timed as to be a godsend to me. ${ }^{2}$

Jefferson, of course, had been succeeded by James Madison, who, though perhaps less ardently than Jefferson, also championed Republican ideals. Jefferson wrote Madison that "it will be difficult to find a character of firmness enough to preserve his independence on the same Bench with Marshall." 3 When he heard that Madison was considering Joseph Story and Ezekiel Bacon, then Chairman of the Ways and Means Committee of the House of Representatives, he admonished Madison that "Story and Bacon are exactly the men who deserted us [on the Embargo Act]. The former [is] unquestionably a tory, and both are too young." 4

President Madison seems to have been "snake-bit" in his effort to fill the Cushing vacancy. He first nominated his Attorney General, Levi Lincoln, who insisted from the first that he did not want the job; even after the Senate confirmed him he still refused to serve. Madison then nominated a complete dark horse, one Alexander Wolcott, a political hack who was the Federal Revenue Collector of Connecticut. The Senate, controlled by his party, rejected Wolcott by the mortifying vote of twenty-four-to-nine. Finally, in the midst of a cabinet crisis that occupied a good deal of this time, Madison nominated Joseph Story for the Cushing vacancy, and the Senate confirmed him as a matter of routine three days later.

Story, of course, fulfilled Jefferson's worst expectations about him. He became Chief Justice Marshall's principal ally on the great legal issues of the day in the Supreme Court, repeatedly casting his vote in favor of national power and against the restrictive interpre-

1. N. SChachner, Thomas Jefferson: A Biography 901 (1951).

2. Id. (1970).

3. G. Dunne, Justice Joseph Story and the Rise of the Supreme Court 77

4. Id. at 78-79. 
tation of the Constitution urged by Jefferson and his states'-rights school. And Joseph Story served on the Supreme Court for thirtyfour years, one of the longest tenures of record.

Presidents who wish to pack the Supreme Court, like murder suspects in a detective novel, must have both motive and opportunity. Here Madison had both, and yet he failed. He was probably a considerably less partisan Chief Executive than Jefferson, and so his motivation was perhaps not strong enough. After having botched several opportunities, he finally preferred to nominate someone who would not precipitate another crisis in his relations with the Senate, rather than insisting on a nominee who had the right philosophical credentials.

The lesson, I suppose, that can be drawn from this incident is that while for Court-watchers the President's use of his appointment power to nominate people for vacancies on the Supreme Court is the most important use he makes of the executive authority, for the President himself the filling of the Supreme Court vacancies is just one of many acts going on under the "big top" of his administration.

Abraham Lincoln had inveighed against the Supreme Court's 1857 decision in the Dred Scott case during his famous debates with Stephen A. Douglas in 1858, when both sought to be elected United States Senator from Illinois. Lincoln lost that election, but his successful presidential campaign two years later was likewise marked by a restrained but nonetheless forceful attack on this decision and by implication on the Court's apparent institutional bias in favor of slaveholders. Within two months of his inauguration, by reason of the death of one Justice and the resignation of two others, Lincoln was given three vacancies on the Supreme Court to fill. To fill them Lincoln chose Noah Swayne of Ohio, David Davis of Illinois, and Samuel F. Miller of Iowa. All were Republicans who had rendered some help in getting Lincoln elected President in 1860; indeed, Davis had been one of Lincoln's principal managers at the Chicago convention of the Republican Party in that year.

In 1863 , by reason of expansion in the membership of the Court, Lincoln was enabled to name still another Justice, and he chose Stephen J. Field of California, a War Democrat who had been the chief justice of that state's supreme court. In 1864, Chief Justice Roger B. Taney finally died at the age of 88 , and Lincoln had an opportunity to choose a new Chief Justice.

At this time, in the fall of 1864 , the constitutionality of the socalled "greenback legislation" that the government had used to finance the war effort was headed for a Court test, and Lincoln was 
very much aware of this fact. He decided to appoint his Secretary of the Treasury, Salmon P. Chase, who was in many respects the architect of the greenback legislation, saying to a confidant that

\footnotetext{
[w]e wish for a Chief Justice who will sustain what has been done in regard to emancipation and the legal tenders. We cannot ask a man what he will do, and if we should, and he should answer us, we should despise him for it. Therefore, we must take a man whose opinions are known. ${ }^{5}$
}

In all, then, Lincoln had five appointments. How successful was Lincoln at "packing" the Court with these appointments? The answer has to be, I believe, that he was very successful at first. In the all-important Prize Cases, decided in 1863, the three Lincoln appointees already on the Court-Swayne, Miller, and Davisjoined with Justices Wayne and Grier of the old Court to make up the majority, while Chief Justice Taney and Justices Nelson, Catron, and Clifford dissented. It seems obvious that this case would have been decided the other way had the same Justices been on the Court who had decided the Dred Scott case six years earlier. Charles Warren, in his The Supreme Court in United States History, describes these cases as being not only "the first cases arriving out of the Civil War to be decided by [the court], but they were far more momentous in the issue involved than any other case; and their final determination favorable to the government's contention was almost a necessary factor in the suppression of the war."6

Immediately after the war, a host of new issues arose that could not readily have been foreseen at the time that Lincoln made his first appointments to the Supreme Court. The extent to which military tribunals might displace civil courts during time of war or insurrection was decided by the Supreme Court in 1866 in the famous case of Ex parte Milligan. ${ }^{7}$ While the Court was unanimous as to one aspect of this case, it divided five-to-four on the equally important question of whether Congress might provide for trial by military commissions during time of insurrection even though the President alone could not. On this point Justices Field and Davis, Lincoln appointees, joined Justices Nelson, Grier, and Clifford of the old Court to hold that neither Congress nor the President might do so, while Chief Justice Chase and Justices Miller and Swayne (all appointed by Lincoln) joined Justice Wayne of the old Court in holding that Congress might establish such courts even though the President alone could not.

During the post-war Reconstruction Era, three new amend-

5. 2 C. Warren, The Supreme Court in United States History 401 (1922).

6. Id. at $380-81$.

7. 71 U.S. (4 Wall.) 2 (1866). 
ments to the United States Constitution were promulgated, and the construction of those amendments was also necessarily on the agenda of the Supreme Court. The first important case involving the fourteenth amendment to come before the Court was that of the Slaughterhouse Cases, in which the applicability of the provisions of that amendment to claims not based on racial discrimination was taken up by the Court. Of the Lincoln appointees, Justice Miller wrote the majority opinion and was joined in it by Justice Davis, while Chief Justice Chase and Justices Field and Swayne were in dissent.

The ultimate irony in Lincoln's effort to pack the Court was the Court's first decision in the so-called Legal Tender Cases, Hepburn v. Griswold. 8 In 1870 the Court held, in an opinion by Chief Justice Chase, who had been named Chief Justice by Lincoln primarily for the purpose of upholding the greenback legislation, that this legislation was unconstitutional. Justice Field joined the opinion of the Chief Justice, while the other three Lincoln appointees-Miller, Swayne, and Davis-dissented. Chief Justice Chase's vote in the Legal Tender Cases is a textbook example of the proposition that one may look at a legal question differently as a judge than one did as a member of the executive branch. There is no reason to believe that Chase thought he was acting unconstitutionally when he helped draft and shepherd through Congress the greenback legislation, and it may well be that if Lincoln had actually posed the question to him before nominating him as Chief Justice, Chase would have agreed that the measures were constitutional. But administrators in charge of a program, even if they are lawyers, simply do not ponder these questions in the depth that judges do, and Chase's vote in the Legal Tender Cases is proof of this fact.

In assessing Lincoln's success in his effort to pack the Court, it seems that with regard to the problems he foresaw at the time of his first appointments-the difficulties that the Supreme Court might put in the way of successfully fighting the Civil War-Lincoln was preeminently successful in his efforts. But with respect to issues that arose after the war-the use of military courts, the constitutionality of the greenback legislation, and the construction of the fourteenth amendment--his appointees disagreed with one another regularly. Perhaps the lesson to be drawn from these examples is that judges may think very much alike with respect to one issue, but quite differently from one another with respect to other issues. And while both Presidents and judicial nominees may know the current constitutional issues of importance, neither of them is usually

8. 75 U.S. (8 Wall.) 603 (1870). 
vouchsafed the foresight to see what the great issues of ten or fifteen years hence are to be.

Probably the most obvious laboratory test for success in packing the Court is the experience of President Franklin D. Roosevelt with his judicial appointments. Franklin Roosevelt had both motive and opportunity in abundance. He was elected President in 1932 , and his first term in office was notable for the enactment of many important social and economic regulatory measures. But it seemed during these four years that no sooner were these New Deal measures signed into law by the President than they were invalidated by the Supreme Court. That Court, referred to in those days as the "Nine Old Men," had on it Justices appointed by Presidents Taft, Wilson, Harding, Coolidge, and Hoover. Though the outcomes in many cases were close, during Roosevelt's first term the Court struck down such important pieces of New Deal legislation as the NRA and the AAA.

In November 1936, President Roosevelt won a landslide reelection victory, with his Republican opponent carrying only the states of Maine and Vermont. Frustrated during his first term by the lack of any vacancies on the Supreme Court, Roosevelt disdained to wait longer for vacancies and in effect took the bull by the horns. In his famous "Court-packing plan" proposed in February 1937, he sought authority from Congress to enlarge the membership of the Court to as many as fifteen Justices; the President would have the authority to appoint an additional Justice for each member of the Court over seventy years of age who chose not to retire. This measure was shot down in flames in the Senate, a Senate that the Democrats controlled by a margin of five-to-one. But in the very course of the battle over this legislation, Justice Van Devanter, who had been appointed to the Court by President Taft in 1910, announced his intention to retire, and during the next four years there occurred six additional vacancies on the Court. The power to remake the Court, which Roosevelt had unsuccessfully sought from Congress, was given him by the operation of the actuarial tables.

There is no doubt that President Roosevelt was keenly aware of the importance of judicial philosophy in a Justice of the Supreme Court; if he had not been, he never would have taken on the institutional might of the third branch with his Court-packing plan. When it appeared during the battle in the Senate over the Courtpacking bill that a compromise might be achieved in which Roosevelt would be allowed to appoint two new Justices, he pondered with several of his intimates whom he might choose, and 
there is little doubt that uppermost in his mind was a judicial outlook sympathetic to sustaining the New Deal legislation.

Within four years of the defeat of the Court-packing legislation, as I have indicated, seven of the nine members of the Court had been appointed by Roosevelt, and in the short run the effect of the change in Court personnel was immediate and predictable. Social and regulatory legislation, whether enacted by the states or by Congress, was sustained across the board against constitutional challenges that might have prevailed before the old Court. When Roosevelt in 1941 appointed Harlan F. Stone to succeed Charles Evan Hughes as Chief Justice, the periodical United States News commented that "the new head of the Court will also find no sharp divergence of opinion among his colleagues." The Washington Post echoed the same sentiment when it foresaw "for years to come" a "virtual unanimity on the tribunal."

These forecasts proved to be entirely accurate in the area of economic and social legislation. But other issues began to percolate up through the judicial coffee pot, as they have a habit of doing. The Second World War, which occupied the United States from 1941 until 1945, produced numerous lawsuits about civil liberties. During the war, the Court maintained a fair degree of cohesion in deciding most of these cases, but quite suddenly after the war, the predicted "virtual unanimity" was rent asunder in rancorous squabbling, the like of which the Court had seldom seen before.

Some, but only some, of the differences were of judicial philosophy. Understandably, seven Justices who agreed as to the appropriate constitutional analysis to apply to economic and social legislation might not agree with one another in cases involving civil liberties. These differences manifested themselves infrequently during the war years but came into full bloom shortly afterwards. In a case called Saia v. New York, 10 the Court held by a vote of five-tofour that a local ordinance of the city of Lockport, New York, regulating the use of sound trucks in city parks, was unconstitutional. Four of the five Justices in the majority were appointees of Franklin Roosevelt, but so were three of the four Justices in the minority. Seven months later the Court all but overruled the Saia case in Kovacs v. Cooper, 11 with one of the Saia majority defecting to join the four dissenters for the Kovacs majority. These two cases provide but one of abundant examples of similar episodes in the Court's adjudication during the period from 1945 to 1949.

\footnotetext{
9. A. Mason, Harlan Fiske Stone: Pillar of the Law 576 (1956).

10. 334 U.S. 558 (1948).

11. 336 U.S. 77 (1949).
} 
In 1949, two events of rather dramatic importance for Courtwatchers, if not for the public at large, occurred within a few months of each other. In July of that year, Justice Frank Murphy died at the age of 59, after having served on the Court for ten years. In September, Justice Wiley Rutledge died at the age of 55, after having served on the Court for six years. Both of these deaths may fairly be described as untimely, and the terms of service of both Justices Murphy and Rutledge were substantially below the average for Supreme Court Justices.

Ironically, these two appointees were the most "liberal" of all the Roosevelt appointees on issues such as civil rights and civil liberties. Harry Truman, then President, replaced them with Justices Tom Clark and Sherman Minton, respectively, who had no doubts about the constitutionality of New Deal economic and social legislation, but who had quite different views of the relationship of the Constitution to civil liberties and civil rights claims from those of Justices Murphy and Rutledge. Here was an element of blind chance that frustrated at least in part the unanimity that had been predicted for the so-called Roosevelt Court: two of President Roosevelt's eight appointees died well before they might have been expected to die, permitting another President to fill the vacancies. One is reminded of the statement of William Howard Taft, speaking with newspaper reporters as he stepped down from the Presidency. Numbering among his most important presidential acts the appointment of six Justices to the Supreme Court, Taft said he had told these Justices: "If any of you die, I'll disown you."

The final factor that frustrated President Roosevelt's complete success in his effort to pack the Supreme Court was a deep personal animosity that developed among several of his appointees. It originally arose between Justice Black and Justice Jackson, but then spread to ally Justice Douglas with Justice Black and Justice Frankfurter with Justice Jackson. The first public manifestation of this animosity was buried in the minute orders denying rehearing in the Jewell Ridge case when the Supreme Court adjourned for the summer in June 1945. The petition for rehearing claimed that Justice Black should have disqualified himself in that five-to-four decision because it was argued by his one-time law partner; Justice Jackson's insistence upon separately stating his views as to the petition for rehearing caused a deep rift between the two Justices.

This unedifying controversy resurfaced the following spring in 1946. Chief Justice Stone died suddenly in April of that year, and President Truman delayed filling the vacancy for a number of weeks. Justice Jackson was at this time Special Prosecutor for the 
United States at the Nuremberg Trials of the Nazi war criminals. He had just wound up his many months' work in Germany, but had not yet returned to the United States. In early June, President Truman announced the appointment of Fred M. Vinson as Chief Justice, and four days later Justice Jackson released an unprecedented statement to the press in Europe, although it was addressed nominally to the chairmen of the House and Senate Judiciary Committees. Jackson then, responding to what he thought were inspired columns in the Washington press reflecting Black's view of the controversy over the Jewell Ridge case, released to the public all the gory details of that case in a light favorable to him. The reaction of the American press and public was one of astonishment that Jackson would air dirty linen in this manner, and of "a plague on both your houses" insofar as the Black-Jackson "blood feud" was concerned.

Jackson and his ally, Frankfurter, had voted differently from Black and his ally, Douglas, in some of the cases to come before the Court before the Jewell Ridge controversy, but one cannot help wondering whether the bitter public antagonism generated by that case exacerbated these differences. The expected "near unanimity" that the Roosevelt appointees were supposed to bring to the Court was frustrated by these antagonisms as well as by the other factors that I have mentioned.

Thus history teaches us, I think, that even a "strong" President determined to leave his mark on the Court-a President such as Lincoln or Franklin Roosevelt-is apt to be only partially successful. Neither the President nor his appointees can foresee what issues will come before the Court during the tenure of the appointees, and it may be that none has thought very much about these issues. Even though they agree as to the proper resolution of current cases, they may well disagree as to future cases involving other questions when, as judges, they study briefs and hear arguments. Longevity of the appointees, or untimely deaths such as those of Justice Murphy and Justice Rutledge, may also frustrate a President's expectations; so also may the personal antagonisms developed between strong-willed appointees of the same President.

All of these factors are subsumed to a greater or lesser extent by observing that the Supreme Court is an institution far more dominated by centrifugal forces, pushing towards individuality and independence, than it is by centripetal forces pulling for hierarchal ordering and institutional unity. The well-known checks and balances provided by the framers of the Constitution have supplied the necessary centrifugal force to make the Supreme Court independent 
of Congress and the President. The degree to which a new Justice should change his way of looking at things when he "puts on the robe" is emphasized by the fact that Supreme Court appointments almost invariably come "one at a time," and each new appointee goes alone to take his place with eight colleagues who are already there. Unlike his freshman counterpart in the House of Representatives, where if there has been a strong political tide running at the time of a particular election there may be as many as forty or fifty new members who form a bloc and cooperate with one another, the new judicial appointee brings no cohorts with him.

A second series of centrifugal forces is at work within the Court itself, pushing each member of the Court to be thoroughly independent of his colleagues. The Chief Justice has some authority that the Associate Justices do not have, but this is relatively insignificant compared to the extraordinary independence that each Justice has from every other Justice. Tenure is assured no matter how one votes in any given case; one is independent not only of public opinion, of the President, and of Congress, but of one's eight colleagues as well. When one puts on the robe, one enters a world of public scrutiny and professional criticism which sets great store by individual performance, and much less store upon the virtue of being a "team player."

James Madison, in his pre-presidential days when he was authoring political tracts, said:

\footnotetext{
But the great security against a gradual concentration of the several powers in the same department, consists in giving to those who administer each department, the necessary constitutional means, and personal motives, to resist encroachments of the others. The provision for defence must in this, as in all other cases, be made commensurate to the danger of attack. Ambition must be made to counteract ambition. The interest of the man must be connected with the constitutional rights of the place. 12
}

Madison, of course, was talking about the principles necessary to secure independence of one branch of the government from another. But he might equally well have been talking about principles, at least in the case of the Supreme Court of the United States, designed to weaken and diffuse the outside loyalties of any new appointee, and to gradually cause that appointee to identify his interests in the broadest sense not merely with the institution to which he is appointed, but to his own particular place within the institution. Here again, this remarkable group of fifty-some men who met in Philadelphia in the summer of 1787 seems to have created the separate branches of the federal government with consummate skill.

12. The Federalist No. 51, at 349 (J. Madison) (J. Cooke ed. 1961). 
The Supreme Court is to be independent of the legislative and executive branches of the government; yet by reason of vacancies occurring on that Court, it is to be subjected to indirect infusions of the popular will in terms of the President's use of his appointment power. But the institution is so structured that a brand new presidential appointee, perhaps feeling himself strongly loyal to the President who appointed him, and looking for colleagues of a similar mind on the Court, is immediately beset with the institutional pressures that I have described. He identifies more and more strongly with the new institution of which he has become a member, and he learns how much store is set by his behaving independently of his colleagues. I think it is these institutional effects, as much as anything, that have prevented even strong Presidents from being any more than partially successful when they sought to "pack" the Supreme Court. 